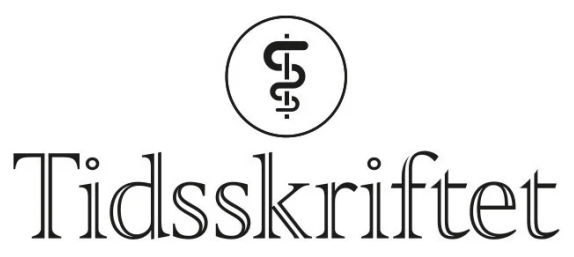

DEN NORSKE LEGEFORENING

\title{
Det menneskelige aspektet ved matematisk modellering
}

DEBATT

\section{SNORRE NILSEN EIKELAND}

snorre.nilsen.eikeland@sus.no

Snorre Nilsen Eikeland har mastergrad i molekylærbiologi og er analytiker i Helse Stavanger. Forfatteren har fylt ut ICMJE-skjemaet og oppgir ingen interessekonflikter.

\section{NILS HENRIK KOLNES}

Nils Henrik Kolnes har mastergrad i teknisk fysikk og er analytiker i Helse Stavanger. Forfatteren har fylt ut ICMJE-skjemaet og oppgir ingen interessekonflikter.

\section{EVEN FLØRENAES}

Even Flørenæs har mastergrad i medisinsk signalbehandling og er analytiker i Helse Stavanger. Forfatteren har fylt ut ICMJE-skjemaet og oppgir ingen interessekonflikter.

Objektiv metodikk i matematisk modellering avhenger av menneskelige vurderinger. Disse påvirker resultatene som brukes som beslutningsgrunnlag av blant annet Folkehelseinstituttet, og som medfører konsekvenser for vaksineprioritering.

At modeller gir objektive estimater, er en sannhet med modifikasjoner (1). Selv om matematikken og resultatene er objektive, er valget av modelltype, antakelser og parametere i høyeste grad subjektive (므). Dette er noe Stanford-universitetet fikk erfare med sin vaksineprioriteringsmodell, som de med rette fikk mye kritikk for $(3,4$.). Algoritmen regnet objektivt ut det den ble bedt om, men mye gikk galt i selve prosessen som førte til at førstelinjehelsearbeidere ikke ble prioritert (5). Selv om man kan velge mange forskjellige antakelser og måle dem opp mot hverandre, så er disse valgene basert på menneskelige vurderinger. Dette er noe vi har erfart i vårt modelleringsarbeid i Helse Stavanger, blant annet i spørsmålet om hvorvidt man skal velge en individbasert modell eller en metapopulasjonsmodell for simuleringer $(\underline{6},-7$.$) .$

Et konkret norsk eksempel er modellering av vaksinestrategier. Folkehelseinstituttet publiserer forbilledlig store deler av metode og antakelser sammen med sine vurderinger (므). Dermed kan man evaluere de menneskelige valgene som er gjort. En vurdering vi 
legger merke til, er at kontakthyppigheten mellom aldersgrupper er basert på en studie fra 2017 (ㅇ) , altså fra en situasjon uten pågående pandemi. Vi kan ikke se at det er gjort justeringer som hensyntar effekten av at mange voksne i større grad har hjemmekontor, effekten av at man er mer forsiktig med å besøke eldre, eller andre effekter en pandemisituasjon har på kontaktmønsteret. I det publiserte materialet er det heller ikke vist at dette valget gjenskaper aldersfordelingen blant de smittede i høst.

«Dersom man ikke vaksinerer aldersgruppene med flest kontakter, kan man ikke si at man har modellert en kontaktbasert strategi»

En annen vesentlig antakelse i modellen finnes i modelleringsresultatene. Her står det at «barn under 18 år ikke antas å få tilbud om vaksine» til tross for at Comirnaty-vaksinen er godkjent fra 16 år og oppover. Videre har Pfizer/BioNTech rekruttert over 2200 barn mellom 12 og 15 år i fase 3-studien og planlegger nye studier for yngre barn (9). Denne antakelsen kan ha stor påvirkning på modellresultatene, da aldersgruppene som ekskluderes, er de med høyest antall kontakter. Dersom man ikke vaksinerer de med flest kontakter, kan man ikke si at man har modellert en kontaktbasert strategi.

\section{Konsekvenser}

Et annet viktig punkt å ta med i debatten om modelleringsarbeid er hvilke konsekvenser antakelsene og resultatene av en modell kan få. For Stanford sin del var det en vaksinasjonsstrategi som åpenbart var urettferdig og feil, men også antakelsene vi har vist til i vaksineprioriteringen fra Folkehelseinstituttet, har konsekvenser. Dersom man antar at kun de over 18 år får tilbud om vaksine, og at «kun rundt $55-57$ \% av befolkningen vaksineres» vil man være under de ca. 70 \% som trengs for å oppnå flokkimmunitet. Noen tiltak vil sannsynligvis fremdeles være nødvendige, men de må i hovedsak rettes mer og mer mot de gruppene som ikke er vaksinert.

\section{«Følger man en aldersstrukturert vaksinasjon fra eldst til yngst etter at risikogruppene er vaksinert, blir konsekvensen at mer og mer av tiltaksbyrden må bceres av de unge»}

Følger man en aldersstrukturert vaksinasjon fra eldst til yngst etter at risikogruppene er vaksinert, blir konsekvensen at mer og mer av tiltaksbyrden må bæres av de unge. Dette er stikk i strid med regjeringens uttalte mål (므). Mens vaksinerte voksne potensielt kan vurdere feriereiser, må ungdom kanskje se enda et år med mindre kontakt med besteforeldre og jevnaldrende, med unntak av egen klassekohort eller de man trener med. Modellresultatene i seg selv er kanskje objektive, men de har reelle konsekvenser når de blir anvendt til beslutningsstøtte. Dette er noe modellerere må ha i tankene og inkludere i analyser og diskusjoner.

\section{Veien videre}

Vi håper og ønsker at åpenheten rundt både valg av antakelser og resultater av modellering fortsetter. Åpenhet gjør at modellene etter hvert blir gradvis bedre når de brukes som diskusjonsgrunnlag. Vårt konkrete forslag er å offentliggjøre hvilken aldersfordeling den individbaserte modellen til Folkehelseinstituttet får dersom man prøver å gjenskape høstens smittespredning. Det vil gi større tillit til modellens parametere eller eventuelt gi 
grunnlag for justeringer basert på endring i kontaktmønstre under pandemien. Resultater fra en lokal modellering av vaksinasjonsstrategi med tilsvarende problemstilling ligger på nettstedet GitHub (11).

Videre hadde det vært bra om man testet forskjellige strategier der startpunktet er satt til etter at alle i risikogruppene er vaksinert. Dette fordi vaksinasjonen av disse, som utgjør ca. $20 \%$ av befolkningen, vil halvere risikoen for innleggelse per smittetilfelle, noe som kan vise seg å være dominerende i forhold til de andre strategiene. Vi foreslår å sammenligne tilfeldig vaksinasjon, fra eldst til yngst, samt tre forskjellige kontaktbaserte simuleringer der man sammenligner å gi vaksinen til 18-, 16- og 12-åringer. Siden den foreløpige vaksinasjonsstrategien ser ut til å være fra eldst til yngst, er det ekstra viktig å sammenligne denne med alternative strategier, spesielt fordi den ikke er en av de fem opprinnelige strategiene som ble sammenlignet.

\section{LITTERATUR}

1. Engebretsen S, Osnes AN. Matematiske modeller under en pandemi. Tidsskr Nor Legeforen 2020; 140. doi: 10.4045/tidsskr.20.0876. [PubMed][CrossRef]

2. Næss H, Pripp AH. Modeller omdanner ikke subjektive inndata til objektive utdata. Tidsskr Nor Legeforen 2020; 140. https://tidsskriftet.no/2020/12/kommentar/modeller-omdanner-ikke-subjektiveinndata-til-objektive-utdata Lest 19.1.2021.

3. Guo E, Hao K. This is the Stanford vaccine algorithm that left out frontline doctors. MIT Technology Review 21.12.2020. https://www.technologyreview.com/2020/12/21/1015303/stanford-vaccine-algorithm/ Lest 19.1.2021.

4. Stanford Letter. 17.12.2020. https://beta.documentcloud.org/documents/20432343-stanford-letter Lest 19.1.2021.

5. Hudson C. On Stanford's COVID-19 Vaccination Algorithm. Haystacks 21.12.2020. https://caitlinhudon.com/2020/12/21/stanford-vaccination-algo/ Lest 19.1.2021.

6. Tømmerbakke SG. Helse Vest: Tiltak har ført til færre innleggelser. Dagens Medisin 30.3.2020. https://www.dagensmedisin.no/artikler/2020/03/30/helse-vest-tiltak-har-fort-til-farreinnleggelser/ Lest 19.1.2021.

7. Hva har vi lært av COVID-19 pandemien? - notat fra virtuell konferanse. https://samforsk.no/SiteAssets/Sider/Forsker-p\%C3\%A5-koronakrisen-umiddelbart--n\%C3\%A5-ernotatet-her/Notat\%2ofra\%2ovirtuell\%2okoneranse_Hva\%2ohar\%2ovi\%2ol\%C3\%A6rt\%20av\%2oCovid19\%20pandemien.pdf Lest 19.1.2021.

8. Folkehelseinstituttets foreløpige anbefalinger om vaksinasjon mot covid-19 og om prioritering av covid-19-vaksiner, versjon 2. Oslo: Folkehelseinstituttet, 2020.

https://www.fhi.no/contentassets/do7db6f2c8f74fa586e2d2a4ab24dfdf/2020-12-v2-anbefalinger-ogprioriteringer-2-utgave-korrigert-forside.pdf Lest 19.1.2021.

9. Pfizer. Our progress in developing an investigational Covid-19 vaccine. https://www.pfizer.com/science/coronavirus/vaccine Lest 26.1.2021.

10. Regjeringen. Langsiktig strategi for håndteringen av covid-19-pandemien. https://www.regjeringen.no/no/dokumenter/langsiktig-strategi-for-handteringen-av-covid-19pandemien/id2791715/ Lest 26.1.2021.

11. Kolnes NH. COVID19model. GitHub. https://github.com/NilsKolnes/COVID19model Lest 26.1.2021.

Publisert: 11. februar 2021. Tidsskr Nor Legeforen. DOI: 10.4045/tidsskr.21.0o6o

Mottatt 21.1.2021, første revisjon innsendt 26.1.2021, godkjent 28.1.2021.

(C) Tidsskrift for Den norske legeforening 2023. Lastet ned fra tidsskriftet.no 26. april 2023. 